\title{
Exploring the Dilemma of Planning for Play in Schools
}

\author{
Russell, Wendy \\ University of Gloucestershire
}

\begin{abstract}
Play presents a dilemma for educators. The world of education is ever more outcome focused, with those outcomes becoming increasingly economic and competitive. Teachers and school leaders feel a pressure to perform well according to externally set standards. Within this context, play becomes problematic unless it can be harnessed in some way to these outcomes. This requires that the value of play be linked to something other than play. Specific kinds of play become valued for the outcomes they are thought to deliver. Planning involves planning the 'rights kinds of play' for the 'right kinds of outcomes'. In this chapter, I explore these assumptions further not to dismiss them entirely, but to see what a critical gaze might offer - and suggest that, valuable though it is, this misses out a lot of what play is about and why this matters for educational institutions. We know that children will play wherever and whenever the conditions are right. Playing is spontaneous and opportunistic, it can go in any direction, and its unique value lies in its intrinsic nature. Given this, predicting outcomes is not only difficult, but it risks turning whatever is planned into something other than play. This paper explores this dilemma, drawing on several conceptual tools from anthropology and philosophy that can help us think about the conditions that support playing in educational settings. In particular, it considers approaches to planning a space that is open for play to emerge.
\end{abstract}

Keywords: spontaneous play, planning for play, space

\section{Introduction}

Play presents a dilemma for educators. The world of education is ever more outcome focused, with those outcomes becoming increasingly economic and competitive. Teachers and school leaders feel a pressure to perform well according to externally set standards. Within this context, play becomes problematic unless it can be harnessed in some way to these outcomes. This requires that the value of play be linked to something other than play. Specific kinds of play become valued for the outcomes they are thought to deliver. Planning involves planning the 'rights kinds of play' for the 'right kinds of outcomes. In this chapter, I explore these assumptions further - not to dis- 
miss them entirely, but to see what a critical gaze might offer - and suggest that, valuable though it is, this misses out a lot of what play is about and why this matters for educational institutions.

The chapter opens with a brief exploration of what the rise in measurement and outcomes focus does in terms of educational policy and practice. Following on from this I consider ways of thinking about play beyond this simple cause and effect instrumentalization. I argue that there are benefits to schools integrating play into their policy, planning and practice that can help them realise their educational goals. Finally, I make the argument that planning for play is less a matter of providing resources and activities with specific outcomes in mind and more of paying attention to the conditions that support playing to emerge. For all of this, I draw on ideas from anthropology and philosophy as well as the research and practice-based experience of our partnership work on the EU Erasmus+ funded CAPS (Children's Access to Play) project which developed and disseminated a kitemark for Play Friendly Schools. ${ }^{1}$

\section{Thinking straight about childhood: how measuring everything affects school life}

Generally, 'thinking straight' is seen as A Good Thing: it is rational, unencumbered by untrustworthy emotions, and brings clarity, legibility and a sense of certainty to life. A straight line from a point of departure to one of arrival (with identified calling points along the way) allows for generalisations and an impression of control. Anthropologist Tim Ingold $(2007,2015)$ calls this 'navigation'.

We can see such navigation in the straight line of child development, which has its predetermined routes between points of birth, infancy, early childhood, middle childhood and adolescence to the destination of adulthood. This straight line is so pervasive that it has become accepted as common sense, difficult to argue against. Yet it is more than a neutral representation: it is performative, in that it influences policies and practices and affects our habits and routines and our everyday relationships with children. Local, national and international measures of progress set standards for children's development at each stage of the journey. The task of those working with children is to ensure they reach such milestones, with additional interventions if children are judged to be at risk of not reaching their full potential.

One such measure is the OECD's Programme for International Student Assessment (PISA). Launched in 2000, it assesses 15-year-olds every three years on their readiness for the world of work, across three domains of reading, mathematics and science. Such measuring is not a neutral practice, however. As Sjøberg (2019, p. 14) states:

\footnotetext{
${ }^{1}$ More information on this project, including resources in 5 European languages, can be found here: http://playfriendlyschools.eu/
} 
The intentions of PISA are, of course, related to the overall aims of the OECD and its commitment to a competitive global free market economy ... It seems "common sense" that high scores on reading, mathematics and science are predictors for the country's future economic competitiveness. Hence, bad rankings on PISA are assumed to be bad signals for the future of the country.

Given this, PISA is a key influence on national and EU education policy and curricula, not just at secondary but also at primary level. Poor performance is a cause for concern, as can be seen in the European Commission's (2019, p. 6) response to the published league tables from the 2018 tests: 'the continued high share of underachievers at EU level is both a worrying social issue and a drag on EU future economic competitiveness'. PISA scores feed into the EU's strategic framework Education and Training 2020 (ET2020), which set benchmarks to be reached across the EU by 2020 and which also informs EU funding.

This example of PISA illustrates the power of economically grounded, universal tests that determine straight lines for governments to navigate, and how this trickles down to education policies and the culture of schools at primary level. The narrative is a very powerful one. It was evident, for example, in the UK government's concern about the closure of schools during the current COVID-19 pandemic, where the talk was about children 'falling behind' and needing to 'catch up'. It is understandable how such a powerful narrative permeates school culture and affects every aspect of school life, including the organisation of the school day. The pressure to perform produces a focus on navigating towards each test.

What does this miss out? How might play fit within such a world of navigation?

\section{Constructions of play time}

Playgrounds and play time are an established feature of school life in most countries. How these spaces and times are valued corresponds with the overall intention of education. In their longitudinal study of English school play times, Baines and Blatchford (2019) found that, although teaching staff value play time as an opportunity for children to have a break from lessons, let off steam, socialize with friends and get some fresh air, largely, 'for many adults, breaks are simply a habitual, relatively unimportant pause in a busy day' (p. 5). The research found that there had been a significant reduction in break and lunch times since 1995; often this is to make more time for teaching and learning in order to meet the demands of the national curriculum, or because of perceived problems associated with playground behaviour. Given that break and lunch times still make up a significant percentage of the time children spend in school (between 16-22\% at primary level in England), it is worth paying a little more attention to it. 
Adult beliefs regarding school playgrounds and play time can be grouped into three perspectives: the romantic playground, the problem playground and the public health playground (Pearce and Bailey, 2011). In the romantic playground, play is the natural state of childhood, exemplified in the move towards outdoor classrooms and nature play (e.g., Prisk and Cusworth, 2018). The public health playground is linked to concerns over obesity and the physical health of children and can be seen in interventions to increase physical literacy and activity (e.g., Willenberg et al., 2010). The problem playground sees play as a distraction from the real purpose of school (learning), or as a site for problem behaviour or for risk of injury or harm (Lester et al., 2011).

\section{Play: a different line of enquiry}

Let's return now to Ingold's lines. These constructions of the playground illustrate straight line thinking - navigating - that aims for specific outcomes from play. What if we think differently about lines? Ingold (2007) contrasts navigating with the more ancient concept of wayfaring. Wayfaring draws on collective memory, landscape, stories, histories; even if the trail has been travelled before, each time offers something different. Wayfarers inhabit, navigators seek to arrive in the most efficient manner possible. Anyone who has ever walked down a street with a three-year-old child will immediately recognise that this is how children inhabit the world: low walls are there for balancing on, fallen leaves are to be picked up, cats to be stroked, slugs to be poked. The journey is what matters, not the arriving, often much to any accompanying adult's frustration. Children are wayfarers, it is the basis for their exploration of and connection with the world, particularly in their play.

Australian children's folklorist June Factor likens children's relationships with school playgrounds to the song lines and story lines of Aboriginal societies: invisible tracks inscribed onto the landscape that 'trace the history, meaning and use of every significant feature of the environment' (Factor, 2004, p. 142). She talks of 'play lines'. What adults may see as the mundane features of playgrounds (tree stumps, drain covers, rubbish bins, cracks in the tarmac, etc.) assume great significance for children's play. Marc Armitage (2005) tells a story of how generations of children at one school used the same drainpipe as a counting pole for chase games, yet the teachers were unaware of its significance. (Had they known what to look for, they would have seen how much the paint on the pipe had worn away over the decades.) Sometimes, these features are destroyed in the name of school playground improvements because adults are unaware of their significance, in the same way that colonisers destroyed sacred lands in Australia and elsewhere.

There is a further element of Ingold's work that is useful in this examination of children's play. In our need to make the world comprehensible, we create what he calls 'blobs'; organisms and phenomena are defined and categorised, fixed within boundaries. We can see this with the attempts to 
define play. Defining is a boundary making practice; it is useful, and at the same time it fixes what is being defined. We argue over what is and is not play, or even what type of play it is. Play becomes separated from the rest of life. Perhaps rather than thinking of play as a separate time and space bound activity, we should recognise its entanglement with all aspects of everyday life. Schools have designated spaces and designated times for playing; this does not mean, however, that these are the only times and spaces where children play, or that everything that happens there/then is play.

In such a world of separation, Ingold suggests that such static blobs have no life, unless they throw out a line. He gives the example of bacteria, which have a blob like cell and a tail: the blob gives energy, the tail motility. Lines give movement, they have vivacity, they can entangle themselves with other lines. What if we think of playing as a wayfaring line rather than a blob, as a process rather than a thing? What if we pay attention to inhabiting play lines rather than navigational straight lines of individual, separate 'blobby' children on their route to adulthood?

When we do this, we inevitably move away from universal generalisations and towards the particular. We can see play erupting in small and lively 'mo(ve)ments' (Curti and Moreno, 2010) interwoven in everyday life. We can also imagine other benefits beyond the important ones of learning specific skills or as a break from learning. Playing offers moments where life is better, but this is more than mere indulgence. Sutton-Smith (2017) suggests that it is the basis of emotional survival. From the high thrill of risk taking to moments of nonsense, fantasy, rude jokes, ghost stories, or just mucking about, children can experience the vitality of raw primary emotions (anger, fear, shock, disgust, happiness and sadness) without the consequences that such behaviour might bring in the 'real' world. These emotions are held in check by the rules of engagement in playing. Of course, this includes forms of playing that adults might find either offensive or dangerous (play is not always 'nice'), but:

play promotes the immediate liveliness of being alive and keeps us emotionally vibrant and capable of joy in an otherwise hostile and scary world (Sutton-Smith, 2017, p. 241).

Why should schools bother about play time? Well, these intrinsic benefits are worthy in their own right and they also relate to more instrumental ones. Our research for the Erasmus+ play-friendly schools project (CAPS) found that:

Children who can find time and space to play are more likely to be happier, more settled and more engaged in other aspects of school life. Aside from the wellbeing benefits the pupils gain from quality play opportunities within the school day, from the perspective of the school, we know that where schools have the conditions right in supporting play, they see a significant decline in behaviour issues and reported accidents, saving hours of teacher time and money in resolving these (Burton et al., 2019, p. 2). 


\section{The dilemma of planning for play}

Playing is spontaneous and opportunistic, it can go in any direction, and its unique value lies in its intrinsic nature as well as its very nonsense and triviality. Given this, predicting outcomes is not only difficult, it risks turning whatever is planned into something other than play. I suggest that we can address the dilemma of planning for play through thinking of play lines and using conceptual tools that come from theories of space. This shifts attention away from navigational straight lines from input to outcome and looks instead at the spatial conditions that can support play.

Space is not merely a physical surface or neutral container, it is produced through interrelations between people, material objects, landscapes, atmosphere, histories - the stories-so-far (Massey, 2005). Henri Lefebvre (1991) suggests that we can imagine three interdependent dimensions to this production of space:

- Conceived space is the space of planners and designers, both physical design and the policies and codes for behaviour, and this is mostly where we see straight-line, navigational thinking. School spaces are designed to control the minds and bodies of the children that attend, in order to support their learning efficiently.

- Perceived space (also called spatial practice) refers to the ways in which individuals participate in the conventions determined by conceived space.

- Lived space is where we see wayfaring: it marks the idiosyncratic and distinctive ways in which conceived space and spatial practices are negotiated, while not being completely constrained by them. This is the space of play, which can be supported both through intentional design and through children's own disturbances of the intentions for space.

In conceived space, the playground can be designed using what we already know in terms of what works. This list of 'ingredients' of a rich play environment is useful:

- material richness and physical diversity

- loose parts and modifiable space

- spaces to hide and survey

- spaces within spaces; networking of spaces

- flexibility

- seasonality and access to nature

- the opportunity to play with the senses (sight, sound, smell, touch and taste); with one's identity (girl/boy, leader/follower, etc); with concepts (such as death or war or marriage) and with the elements (earth, water, air and fire $)^{2}$

- an overall playful feel (Burton et al., 2019, p. 48).

The last item on the list deserves a little more explanation: this is about the culture rather than the physical design, although in terms of the produc-

${ }^{2}$ This is what Bob Hughes (2012) refers to as the 'playwork curriculum' 
tion of space, these cannot be separated. Yet this is where the tension arises in Lefebvre's spatial triad. We cannot plan lived space (for that would make it conceived space); all three dimensions are important. The overall playful feel is produced through developing a culture over time that says it is ok to play here. It can be supported by design and policies and particularly by staff attitudes. Everything flows from that. More details on this can be found in the play-friendly schools handbook (Burton et al., 2019).

In playing with the dilemma of planning for play, the twin concepts of account-ability and response-ability (Lester, 2020) are useful. Account-ability is about how to account for children's play, acknowledging how it emerges from whatever is to hand in ways that enliven things. It requires paying attention to the small details of children's relationship with space and time, their play lines, but not with the intention of colonising them. Response-ability is about holding up to critical scrutiny the spatial habits and routines to see how spaces can be made more open for playing.

\section{Final words}

This chapter has drawn on Ingold's work on lines, and particularly the distinction between navigation (clear, efficient routes between points towards a known destination) and wayfaring (dwelling in a shared landscape that acknowledges stories that have come before and are yet to come) in order to consider the dilemma of planning for play in schools. The production of space by more powerful adults makes assumptions about the value of spacetime for children's education and for the future of national economies. Children, however, are proficient at finding spacetime for playing in the cracks left behind after adult orderings. Planning for play becomes a matter of developing an awareness of children's relationship with spacetime and working to support that.

\section{References}

Armitage, M. (2005). The Influence of School Architecture and Design on the Outdoor Play Experience within the Primary School, Paedagogica Historica, 41(4), 535-553.

Baines, E. \& Blatchford, P. (2019). School Break and Lunch Times and Young People's Social Lives: A follow-up national study. UCL Institute of Education.

Burton, L., Russell, W., Suhajda, E. V. \& Vastag, Zs. (2019). The Play-Friendly School label. A handbook for schools. University of Gloucestershire

Curti, G. H. \& Moreno, C. M. (2010). Institutional Borders, Revolutionary Imaginings and the Becoming-Adult of the Child. Children's Geographies, 8(4), 413-427.

European Commission (2019). PISA 2018 and the EU: Striving for social fairness through education. Publications Office of the EU. 
Factor, J. (2004). Tree Stumps, Manhole Covers and Rubbish Tins: The invisible play lines of a primary school playground. Childhood, 11(2), 142-154.

Hughes, B. (2012). Evolutionary Playwork 2nd edition. Routledge.

Ingold, T. (2007). Lines: A brief history. Routledge.

Ingold, T. (2015). The Life of Lines. Routledge.

Lefebvre, H. (1991). The production of space. trans D. Nicholson-Smith, Blackwell.

Lester, S. (2020). Everyday Playfulness: A new approach to children's play and adult responses to it. Jessica Kingsley.

Lester, S., Jones, O. \& Russell, W. (2011). Supporting School Improvement through Play: an Evaluation of South Gloucestershire's Outdoor Play and Learning Programme. National Children's Bureau.

Massey, D. (2005). For space. Sage.

Pearce, G. \& Bailey, R. (2011). Football Pitches and Barbie Dolls: Young children's perceptions of their school playgrounds. Early Child Development and Care, 181(10), 1361-1379.

Prisk, C. \& Cusworth, H. (2018). From Muddy Hands and Dirty Faces ... to Higher Grades and Happy Places: Outdoor learning and play at schools around the world. Outdoor Classroom Day.

Sjøberg, S. (2019). The PISA Syndrome: How the OECD has hijacked the way we perceive pupils, schools and education. Confero, 7(1), 12-65.

Sutton-Smith, B. (2017). Play for Life: Play theory and play as emotional survival. The Strong Museum.

Willenberg, L. J., Ashbolt, R., Holland, D., Gibbs, L., MacDougall, C., Garrard, J., Green, J. B. \& Waters, E. (2010). Increasing School Playground Physical Activity: A mixed methods study combining environmental measures and children's perspectives. Journal of Science and Medicine in Sport, 13, 210-216.

Russell, Wendy: https://orcid.org/0000-0002-5028-6428 